\author{
Makarenko, I. \\ Institute of Evolutionary Economics, \\ 45, Raiduzhna St., Kyiv, 02218, Ukraine \\ +380 66294 8780, makariee@gmail.com
}

\title{
SCIENTIFIC HERITAGE OF MYKHAILO TUGAN-BARANOVSKY (on the occasion of the anniversary of the foundation of innovation economics theory in Europe and the anniversary of the National Academy of Sciences of Ukraine)
}

In 2019, it will turn 125 years since, in 1894, the book Industrial Crises by Mykhailo TuganBaranovsky [1] was published. This research laid the foundations of modern innovation theory of economic development. Its results changed the understanding of economy in the world and have not lost their edge till nowadays.

Based on the study of industrial crises from which, economies of United Kingdom and the United States were suffering in the $19^{\text {th }}$ century, the prominent Ukrainian economist Mykhailo Tugan-Baranovsky [1] developed the theory of periodicity of industrial crises. Especially important is his conclusion on the economic cycle, which explains crises as one of its four phases.

Intensive discussions among European scholars, which arose around the search for the causes of cyclical fluctuations eventually had led to the theory of innovations by Joseph Schumpeter who explained the crisis as the adaptation of the economy to the changes induced by innovation ... [3], and the property of innovation to lap the economy as a wave [4].

Tugan-Baranovsky's research [1] triggered a wave of studies of currency and financial crises.

(C) MAKARENKO, I., 2018
The theory of economic cycles has become a fundamental work for the further study of the macroeconomic environment - interest rates and exchange rates - that affects fluctuations in capital flows which, according to Joseph Schumpeter, is an important factor for managing the development of economy and innovation.

Tugan-Baranovsky's research [1] had contributed to new developments, which eventually became components of the innovation theory that led to a worldwide discussion on the causes of crises and their mechanisms. Below, there is a very short list of new areas in science, which had arisen from Tugan-Baranovsky's conception of economic dynamics cyclicality, which, in turn, had laid the foundations for almost all economic and social sciences related to economic development:

+ Joseph Schumpeter's theory of innovation development (1911-1947, The Theory of Economic Development [3], Business Cycles [4]);

+ the theory of the role of investments in science, technology, and new territories by Arthur Spiethoff (1902, Vorbemerkungen zu einer Theorie der Überproducktion [5]);

+ the theory of cycles of the economic conjuncture by Nikolai Kondratiev (1928, Big Cycles of the Conjuncture [6]); 
+ Albert Aftalion's theory of the demand effect on production (1909, Crisis of Overproduction [7]);

+ the theory of interest rate dynamics by Knut Wicksell (1936, Interest and Prices [8]), Irving Fisher (1930, Theory of Interest [9]), and J.M. Keynes (1936, General Theory of Employment, Interest and Money [10]);

+ the theory of business expectations by Arthur Pigou (1927, Industrial Fluctuations [11]);

+ the effect of the accelerator and the derived demand by J.M. Clark (1934, Strategic Factors in Business Cycles [12]);

+ the theory of non-equilibrium in the monetary sphere by Friedrich von Hayek (1935, Prices and Production [13]).

Tugan-Baranovsky's research Periodical Industrial Crises [1] secured his leadership in the six areas. He was the first one whose contribution to a new branch of science, economic dynamics, had been recognized and appreciated in Europe. English economist John Maynard Keynes called him the most prominent Slavic economist.

Secondly, he was the first to understand and to show the nature of economic crises, thereby triggering a series of economic studies related to this problem. The burst of attention towards the economic cycles had resulted in such outstanding discoveries as Joseph Schumpeter's innovations and in the appearance of economic schools that dealt with problems of anti-cyclical and anti-crisis regulation of economic processes all over the world.

Thirdly, Mykhailo Tugan-Baranovsky described the monetary and financial crises as exemplified by inflows and outflows of gold from central banks (and between central banks) of England and the United States.

Fourthly, he was the first who described the mechanisms of sudden stops of capital and sudden stops of systems.

Fifthly, the scholar described the crisis mechanism of economic systems under a fixed exchange rate that at that time was the Golden Standard and chronologically accurately outlined in detail the sequence of processes that inevitably led the system to a monetary and financial crisis.
Sixthly, Tugan-Baranovsky was the first who described the cyclicality and cycles of domestic financial flows.

In addition to the above, it has recently been found out that he was a pioneer of the theory of cyclical nature of external financial flows and their sudden stops.

At the end of the $20^{\text {th }}$-beginning of the $21^{\text {st }}$ century, world emerging markets with fixed exchange rates underwent crises. Modern studies of these phenomena again drew attention of scholars towards Tugan-Baranovsky's Industrial Crises [1], confirming the relevance of this genius work.

The study of the Asian crisis of 1997-1998 by experts from the London Institute for Development [14], the Inter-American Development Bank (BID) [15, 16], the Swiss Bank for International Settlements (BIS) [17], and the World Bank [18] identified the cause of its occurrence, as a stop of capital flows. G. Calvo called it "the effect of a sudden stop of capital" and "the effect of systemic sudden stop, (SSS)". As it was widely recognized, the effect was aptly named, and G. Calvo, for a while, was considered a pioneer in this field. However, R. Dornbush found that earlier (in 1928), an American scholar, Frank Taussih, referred to this effect as he pointed out that the main reason for the crisis was not the rate of capital flows, but their sudden stop. The sudden stop of capital inflows, which is followed by capital outflow, occurs as a result of growing external deficit and increasing real exchange rate. In other words, the sudden stop occurs under the current account crisis, which is explained by financing the current account deficit at the expense of capital inflow $[19,48]$.

The Figure shows the economic mechanism of sudden stops in national economies of Eastern Asia in 1997, where within a few weeks, capital flows stopped and reversed. The exchange rate (and GDP) fell down, and BOP current account balance almost immediately changed from deficit to surplus as import declined while export grew.

However, having carefully studied Industrial Crises [1], one can see that for Mykhailo Tugan- 
Asian Crisis

Indonesia, Korea, Malaysia, Philippines, and Thailand

USD million
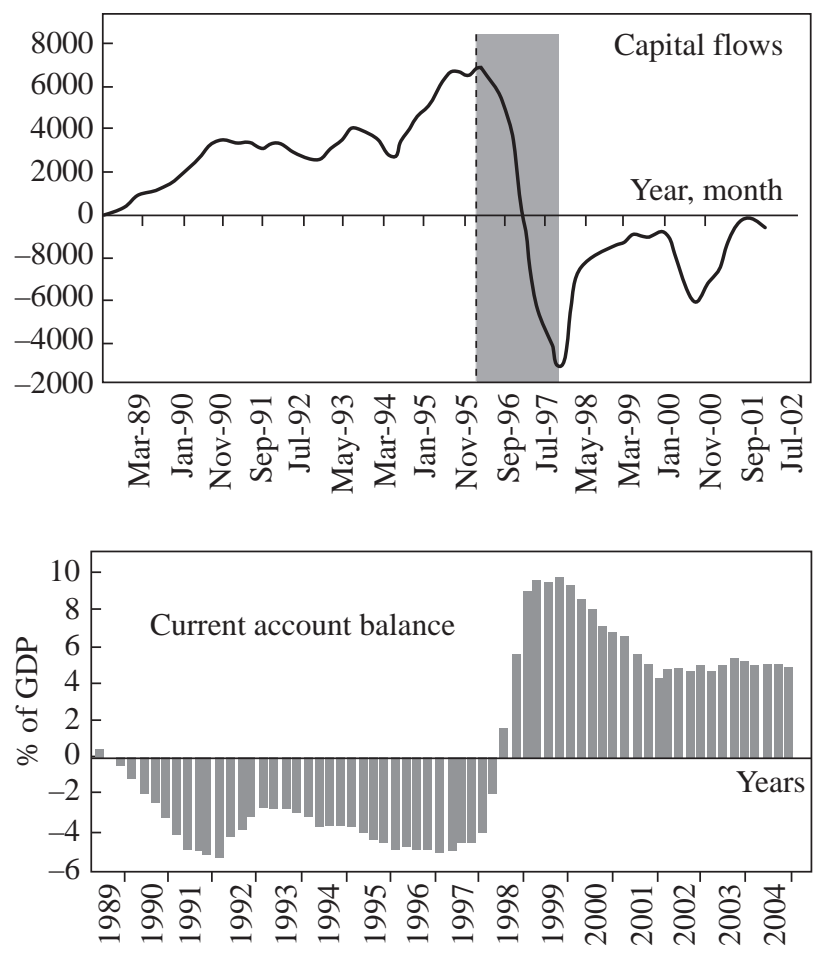

Boom and Decline of Capital Flows

(\% of GDP. the last four quarters)

\begin{tabular}{|l|c|c|c|}
\hline \multirow{2}{*}{} & Boom & \multicolumn{2}{|c|}{ Decline } \\
\cline { 2 - 4 } & $\begin{array}{c}\text { 1996 peak } \\
\text { to 1984-88 } \\
\text { average }\end{array}$ & $\begin{array}{c}1998 \\
\text { to 1996 } \\
\text { peak }\end{array}$ & $\begin{array}{c}2002 \\
\text { to 1996 } \\
\text { peak }\end{array}$ \\
\hline Thailand & 9.7 & -22.6 & -11.2 \\
Indonesia & 2.6 & -21.9 & -7.0 \\
Korea & 6.4 & -14.5 & -3.2 \\
Philippines & 8.0 & -10.3 & -14.8 \\
$\begin{array}{l}\text { Malaysia } \\
\text { Five countries of } \\
\text { South-East Asia }\end{array}$ & 6.1 & -6.7 & -10.9 \\
\hline
\end{tabular}

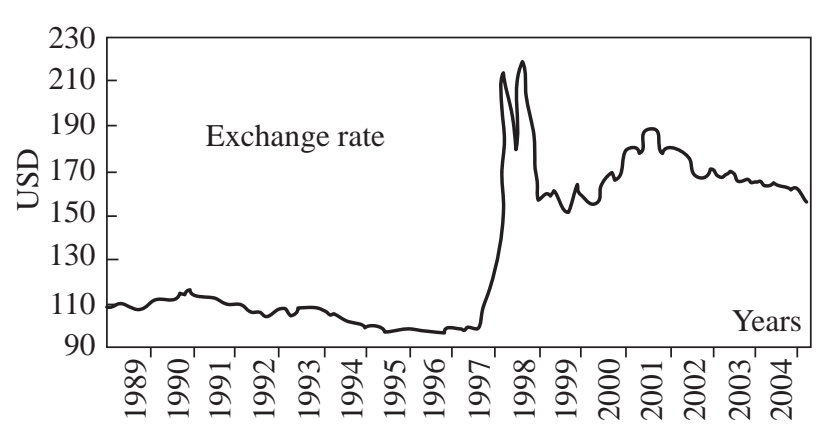

Sudden stop in South-Eastern Asia in 1997

Source: Calvo and Talvi (2005) and Calvo, Izquierdo and Talvi (2006) [17].

Baranovsky, the effect of sudden stops is a cornerstone in describing the causes of industrial crises in the Great Britain, the United States, and later throughout Europe. Therefore, Tugan-Baranovsky must be reasonably considered a pioneer in this field.

The world significance of Industrial Crises by Mykhailo Tugan-Baranovsky [1] becomes more clearly evident if to draw a parallel between his work and the scientific heritage of John Maynard Keynes [10] as all further world studies of macroeconomics are in line with Keynesian Revolution, while all subsequent world studies of economic dynamics, including innovative and evolutionary processes, appeared to be a legacy of Tugan-Baranovsky's ideas. This fact puts Ukraine in the forefront of the countries that have made a major contribution to the development of world civilization. This research [1] translated into other languages has become mandatory for studying economic disciplines in all world leading universities.

Mykhailo returned to Ukraine in the summer of 1917. For a short period, he was the Minister of Finance in the UPR government. In 1918, together with V. Vernadsky, A. Krymsky, and M. Vasilenko he became a co-founder of the Ukrainian Academy of Sciences, the chairman of its socio-economic department, and the founder of the Institute for the Study of Economic Situation and the Institute of Demography.

Mykhailo Tugan-Baranovsky was born and died in Ukraine. He considered himself Ukrainian. This was the main reason why this prominent scholar chose Ukraine as a place of life in his mature years. 


\section{REFERENCES}

1. Tugan-Baranovsky, M.I. Industrial crises in Modern England, Their Causes and Effect on People's Life Saint Petersburg, I.N. Skorokhodov Publishing House, 1894. 512 p. (in Russian)

2. Juglar C. Des Crises commercialese. Paris, 1889.

3. Schumpeter J.A. Business Cycles. New York, 1939.

4. Schumpeter J. The Theory of Economic Development. Cambridge, 1934; Schumpeter J. The Theory of Economic Development: an Inquiry into Profits, Capital, Credit, Interest, and Business Cycle Kyiv, 2011. 242 p.

5. Spiethoff A. Vorbemerkungen zu einer Theorie der Überproduktion. Jahrbuch für Gesetzgebung..., 1902. s.730.

6. Kondratiev, N.D. Big cycles of Economic Conjuncture. Reports and Their Discussion at the Institute of the Economics. Moscow, 1928, 526 (in Russian)

7. Aftalion A. The Theory of Economic Cycles Based on the Capitalistic Technique of Production. Review of Economic Statistics, October, 1927. No. 9, pp. 165-70.

8. Wicksell K. Interest and Prices. London, 1936.

9. Fisher I. Theory of Interest. New York, 1930. 331 p.

10. Keynes J.M. General Theory of Employment, Interest and Money. London, 1936. 394 p.

11. Pigou A.C. Industrial Fluctuations. London, 1927. 25 p.

12. Clark J.M. Strategic Factors in Business Cycles. National Bureau of Economic Research, 1934. 256 p.

13. Hayek F. Prices and Production. London, 1935. 162 p.

14. Schneider Benu. Issues in Capital Account Convertibility in Developing Countries. Overseas Development Institute. London, 2000. - URL: http://www.odi.org.uk/resources/details.asp?id=4807\&title=issues-capital-account-convertibilitydeveloping-countries $(30 / 11 / 2018)$.

15. Calvo Guillermo A., Izquierdo Alejandro, Mejia Luis-Fernando. On the empirics of sudden stops: the relevance of balance-sheet effects. Inter-American Development Bank (BID), Research Department Working Papers \#509, July 2004. 48 p.

16. Calvo Guillermo A., Izquierdo Alejandro, Mejia Luis-Fernando. Systemic sudden stops: the relevance of balancesheet effects and financial integration. Inter-American Development Bank (BID), Research Department Working Papers \#637, July 2008. 43 p.

17. Calvo Guillermo A., Izquierdo Alejandro, Talvi Ernesto. Phoenix miracles in emerging markets: recovering without credit from systemic financial crises. BIS Working Papers \#221, December 2006.35 p.

18. Kawai Masahiro, Newfarmer Richard, Schmukler Sergio. Crisis and contagion in East Asia: nine lessons. The World Bank East Asia and Pacific Region Office of the Regional Vice President and Macroeconomics and Growth. Polisy Research Working Paper 2610, June 2001. 56 p.

19. Rudyi, K.V. Financial Crises: Theory, History, Politics Moscow, 2003, 399 p. (in Russian) 